\title{
DID LOCALISATION OF COMMUNITY- BASED CONSERVATION SUCCEED? A CASE STUDY ON COMMUNITY-BASED SEA TURTLE CONSERVATION IN MA'DAERAH SEA TURTLE SANCTUARY
}

\author{
TSUJI Shyuji \\ Department of Southeast Asian Studies \\ Faculty of Arts and Social Sciences \\ University of Malaya \\ (ugh86229@nifty.com)
}

\begin{abstract}
Community-based conservation is increasingly drawing attention in South East Asian countries. However, the approach is not necessarily compatible with administration style preferred in some Asian developing nations. The study examines how the new approach was interpreted and transformed in the course of its localisation and how community members reacted with the unfamiliar attempt, through a case study on Ma'daerah sea turtle sanctuary project conducted in Terengganu State, Malaysia.
\end{abstract}

Keywords: Conservation, Community, Sea turtle, Localisation, Passive Resistance

\section{Introduction.}

Since the 1990s, community-based conservation has drawn attention as an innovative approach to conservation. In South East Asia, the approach has been adopted since the late 1990s for wildlife conservation, forest management, fishery resource management, and cultural heritage safeguarding. The 2003 Convention for safeguarding intangible cultural heritage even stipulates that all the safeguarding measures shall be community-oriented. However, adopting the approach is not an easy task for 
some Asian developing nations where both government officers and people have been familiar with centralised administration. How is a communitybased project introduced, implemented and evaluated? This is the theme of the paper.

The case dealt in the paper is Ma'daerah sea turtle sanctuary project, which was launched as the first community-based conservation project in peninsular Malaysia in 1999. The sanctuary is located at Kerteh in the State of Terengganu. Based on field works in Terengganu State (March- August 2007, November 2007- February 2008), the study describes how have local elites discussed on community-based conservation, how have the officers conducted the project, and how to do the local fishermen. It is one of the core targets of the project, responded to the project.

The methodology of the study is qualitative. It includes document survey at the archive of the economic planning unit of the state, key informant interviews, and a semi-structured interview with 22 fishermen at two settlements ${ }^{1}$. The records of interviews with fishermen are coded through grounded theory approach ${ }^{2}$.

\section{Literature}

The original concept of community-based conservation was incorporated with the promotion of grass-roots style democracy and empowerment of the weak such as female and indigenous people. The founders of the approach strongly recommended participation of the local people in decision-making processes. They even envisaged that citizens can develop new skills such as negotiation, communication, active listening, group process, and coalition-building, based on their case studies on the environmental dispute settlements (Crowfoot \& Wondolleck, 1990). For them, to reform both government administration and local social structure has as much significance as to conserve wildlife, if not more. The following passages reveal ideas underlying community-based management clearly:

Community-based conservation envisions to change local political and social structures. In community-based conservation, the emphasis has moved from the top to the bottom, from the centre to the periphery, from the elite to the poor, and from the urban to the rural. The shift has opened the door on the biggest conservation challenge of all: (Snap)

Community-based conservation reverses top-down, centre-driven conservation by focusing on the people who bear the cost of conservation. In the 
broader sense, then, community-based conservation includes natural resources or biodiversity protection by, for, and with the local community (Western \& Wright, 1994. p.7).

Nonetheless, Campbell (2007) illustrated that a community-based conservation, in reality, respected local people much less than being imagined, through her series of papers on community-based sea turtle conservation in Costa Rica. Having based on interviews with scientists; NGOs members; and government officers, she criticised that the experts' notion encompasses only narrow sense of empowerment. Campbell illustrated that they hardly agree to allow the people to join the decision-making process, even though most of these experts admitted participation of the local people is necessary. She criticised as follows:

Participation, in mind-set of such experts, meant employing the people as conservation staff, educating them to install pro-conservation mind, and collecting information from them (Campbell, 2007).

Campbell and Smith (2006) also examined mindsets of volunteers who partake in sea turtle conservation. She found that the volunteers regard fishermen as the central problem and the main target of enlightenment. She nonetheless criticised their ideas because they failed to link the plight of sea turtles to wider issues of environmental quality; they instead criticised the local consumption as if it were the only factor to endanger the reptile. The findings of the works of Campbell above remind us the political aspects of communitybased conservation. Her criticism against asymmetricity of the power between the experts and fishermen casts a fundamental question against communitybased conservation.

Some literature on marine wildlife conservation in Thailand also illustrated the inadequate performance of community-based conservation projects. Yamao (1997) examined fishery resource co-management projects and attributed their dormant status to three problems: conflict of many objects of the projects, dependency on the government of people to hamper voluntarism, and the oligopoly of projects' benefit by special members. Having studied Dugong conservation, Hines (2002) pointed out the lack of mutual trust between the government park officials and the local community during the early stages of the project that gave prolonged negative impacts. Womgbursarakum (2002) conducted a participatory observation in marine parks and found out passive resistance of the local fishermen: They neither 
violently resisted nor expressed objection against the project. They just smiled but shun the project. Disregard and indifference were in the form of resistance of the local fishermen.

Concerning to the perception of the local fishermen in Terengganu, the author depicted that the local fishermen were aware of the endangered status of the turtles, concerned sustainability of their fishing grounds, and did not feel serious opportunity cost about the conservation programmes (Tsuji, 2010). He, however, pointed out the sense of being victimised, sense of powerlessness, and tendency to depend on government could lead to psychological barriers that might prevent fishermen from actively participate in conservation programmes.

Having introduced the literature, the paper proceeds to examine how the original concept have been localised, how the project was implemented in field level, and how fishermen reacted to the project. To examine these points, our argument will be narrowed down to the case of Ma'daerah sea turtle sanctuary.

\section{Localisation of the concept}

This section examines how the visions of local elites concerning the relationship between conservation projects and community. The examined documents are the record of the "Workshop on sea turtle conservation and management in Malaysia" held in 1987(Unit Perancangan Ekonomi Negeri Terengganu \& Department of Fishery Malaysia, 1987), a report titled "The effect of fishing on leatherback turtles" by WWF Malaysia in 1988(Aikanathan \& Kavanagh, 1988), the record of "ASEAN program and work plan for Sea turtle conservation" held in 1997 (ASEAN Secretariat, 1997), and the Proceedings of the "Workshop of charting multidisciplinary research and action priorities towards the conservation and sustainable management of sea turtle in the Pacific Ocean" published in 2006 (Ahmed et. al., 2006).

The record of the 1987 workshop shows us that local elites have discussed on the relationship between sea turtle sanctuary and local fishermen from three decades ago. One of the central topics of the 1987 workshop was an environmental education for the local people. The adopted work plan included "To educate coastal population to identify the different kinds of sea turtles and to aid the collection of information", "To highlight the subject of the plight of local sea turtles and the value of wildlife heritage", and "To develop voluntary groups among the local public and conservationists to assist in education campaigns and beach clean- up programmes, beach patrolling"3 ${ }^{3}$ The point 
here is that education meant to provide biological knowledge given mobilising local people and to infuse them affinity toward turtles. They premised that local people had neither sufficient knowledge nor awareness toward the value of the natural heritage. Further, the participation of the local people purely aimed at facilitating enforcers. Little attention was paid to the villagers.

The report published by WWF Malaysia in 1988 recommended thorough explanation of the conservation policy to the fishery community to avoid their resentment. The point is that local elite recognised opportunity cost borne by the local people and its negative impacts on the conservation project, while they did not admit the necessity for compensation. What was recommended was to persuade local people.

Unlike these domestic arguments, ASEAN program and work plan for sea turtle conservation and protection published in 1997 reflected idealism of the original concept of community-based conservation. It demonstratively encouraged to "involve local communities in the development and implement a protocol for the management of sea turtle habitats" and to "develop alternative avenues of income and cultural utilisation ${ }^{4 "}$. The document tells us that concept of community-based conservation was obviously introduced to relevant government officers at the time of the late 1990s.

Just three years after the first community-based conservation project was launched in Ma'daerah, The workshop of charting Multidisciplinary research and action priorities towards the conservation and sustainable management of sea turtle in the Pacific Ocean was held. Local participation was one of the main agenda in this conference. Participants from Malaysia commonly introduced Ma'daerah project as the pilot case for this attempt. Y.A.B. Datuk Seri Idris bin Jusoh, the Chief Ministry of Terengganu remarked "the work of conservation does not lie principally with the animals, plants, and ecosystem but lies in dealing with humans" (Jusoh, 2006). Sequentially, he stressed the importance of "smart partnership with non-government bodies and private sectors must be enhanced to alleviate the mammoth task of conservation into a successful and fruitful affair. The Roundtable discussion at that meeting also mentioned the importance of including local community into management as follows:

Public awareness is identified as essential. Integrated dialogue encourages them to establish a formal committee to be headed by the state secretary. This committee should consist of relevant state and federal agencies as members, and also representatives from non-governmental agencies and community-based organisations. (Snap) 
Empowerment of local communities, like fishers and egg collectors, to manage and protect turtles and their eggs through a community-based management system could solve some of the enforcement problems (Ibrahim and Sharma, 2006) ${ }^{5}$.

The statement above has two notable features. First, it reiterated leading role of the government, even though it mentioned the participation of the community. Grassroots autonomy emphasised by the original concept was replaced by "smart partnership between public and private sector". Second, it proposed participation of local people in expectation of labour force for enforcement.

Up to here, this section reviewed the visions of the local elites concerning the relationship between conservation and community. Enlightenment, leading role of the government and mobilisation of the labour force have been basic ideas behind political arguments. The idealism of the original concept was not faithfully installed, even though the 1997 ASEAN meeting stressed it.

\section{Dialogue with fishermen}

The previous section reviewed how local elites interpreted and absorbed the concept of community-based conservation. Next topic to be argued is how the project managers implemented the community-based project in field level. This section will explore the topics through key informant interview. The focus of the discussion here is the programme called dialogues with fishermen, which was introduced as the main avenue to achieve a horizontal partnership between the managers and local people(Department of fishery Malaysia; WWF-Malaysia; and BP Malaysia, 2004). The fishery officer who had often conducted dialogue sessions in the field described how he handled the sessions to be as follows:

The almost issue at sessions is about the net we banned before, actually, pukat pari. Pukat pari is one of the issues there. So when we discuss in the dialogue with the local people from there, most fishermen from there take note. When somebody put the net into the sea, guys; I mean local people from there call us to make enforcement from our office. That is good. I think, now collaboration of local people and department of fishery for this effort is good ${ }^{6}$.

The fishermen, they have few groups like big boats (owners' group) and fibre boats, and small boats. The opinion from small boat fishermen there was just where pukat pari are, where it is. They gave us the location of the net in the sea'. 
These remarks tell us that the sessions are used in reality as an opportunity to penetrate existing policy and to facilitate enforcement. On the other hand, it is questionable that the sessions pave any path for dialogue. Informants having attended dialogue sessions further described how fishermen behaved at sessions:

They wouldn't say to me; they just say "I don't want conserve". They will just say "Yeah, yeah, yeah, yeah!" But still, they don't do. It is tous.

Usually, fishermen ask about laws and the enforcement of the regulations. These question will be answered by officers from the Department of Fisheries because our community group only aims at raising awareness on why the fishermen need to cooperate with us. ${ }^{9}$

Judging from these remarks, these sessions have no function for decision-making. Moreover, in reality, little interaction between the managing parties and fishermen occurred at the sessions. Informants also mentioned that only about half of fishermen attended the session and, to make the problem worse, fishermen have increasingly lost interest in the sessions:

We called for fishermen to discuss fishing gears they use. Specifically, we discussed use of pukat pari they catch stingrays. These are illegal because they bycatch turtles. The thing is that only the good fishermen came, the bad fishermen using pukat pari don't want to come. It did go hard to reach them ${ }^{10}$.

As far as I know, many fishermen once participated in the project including fishermen from Paka, Kerteh, Kemasik and the committee members in the region themselves. In the early stage, many fishermen participated. Now, the number of participants is getting less and less as I assume. The rest of the members are only teachers ${ }^{11}$.

In the early stage, fishermen like us, like my relatives and friends, supported the project. Now I don't want to help it. I assume many parties, including myself, have withdrawn from the community-group ${ }^{12}$.

Why local fishermen lost interest in the dialogue session? The next section further the argument based on a semi-structured interview with fishermen.

\section{Fishermen's passive resistance}

Being consistent with the explanation of the key informants, a respondent vividly descried "evasion of the programmes" by particular fishermen as follows: 
They have conducted campaigns, held meetings and everything else for the purpose of conservation. They have already held gatherings, dialogue sessions, and even roadshows. However, some particular fishermen have already avoided, yes, deliberately avoided these programmes. They do understand what the purpose of these programmes is. Their reaction is, however, to intentionally shun the project. They ignore notifications and operate their job as usual. It means that they do not want to know, they do not want to be directed. Only half of fishermen respect the project and take the appeal of WWF into consideration. This is the problem ${ }^{13}$.

This evasion of programmes is deemed to be a form of passive resistance performed by the fishermen. Without violence and harsh words, indifferent fishermen rejected the project silently.

Three concepts emerging from interviews explains the reason for the indifference. Firstly, fishermen considered that the programs conducted in villages were directed to an "improper target":

Of course, the officers always monitor the sea. They also offer lectures. However, the lectures are provided with those who do not use trawling nets. Trawlers obviously come from the outside. They are from Pahang and Johor ${ }^{14}$.

Fishermen mainly attributed sea turtle decline to powerful outsiders such as big trawlers and commercialised foreign fishing vessels. In their recognition, they were not culprits of the decline of the turtles and degradation of the marine ecosystem. In line with this recognition, conservation efforts should concentrate on clamping down small operations of the large commercial boats rather than raising awareness of small-scale fishermen from vicinal villages. Fishermen were also sceptical to the advantage of conservation programmes held in geographically limited sanctuary alone. The scepticism also rooted in recognition that major threats to sea turtles came from outside of the villages; conservation programmes "on only one beach" would hardly solve actual problems. Moreover, they found contents of educational programmes and dialogue sessions were same old stories because they felt they had already been aware of the endangered status of turtles. Respondent no.22 explained this point in detail:

The WWF's activities always remain same. I can help them by monitoring, collecting information on why sea turtles in this area are found dead and stranded on the beach, how many turtles are dead, what killed them and so on. We have provided that information to them. We informed them when a turtle had 
been killed by getting entangled with ropes or some other causes of death. Such incidents, however, do not occur daily. They might happen once every two years but would not occur every day. They are extremely rare incidents, even though once in a while, a turtle do get killed by incidental capture. Next month, they also ask about same things. They also ask the same questions in meetings every other months or year. We do not have anything special, anything new. This is why we got bored with no activities. ${ }^{15}$

Fishermen also criticised that community-based conservation was not practical because its main activities seemed to be nothing more than "pile of meetings". This criticism results from insufficient understanding about concepts of community-based management. While community-based conservation entails many sessions with community members, fishermen regarded these meetings as wasteful. Ironically, mangrove planting programme, held by another environmental NGO namely Eco-Care, served as a catalyst to give the unpractical impression to the sea turtle conservation programme:

During all the period I have participated in, WWF's community-group did little activities. Compared with meetings, their activities were far fewer. Then, I had to withdraw myself from the group. It, for me, seemed to hold many meetings, while the group did not work, did not conduct activities. ${ }^{16}$.

The community group conduct various activities, but I couldn't see its achievement. For me, it seemed to achieve no outcome and fail to raise awareness as Optima's Eco-care did. Eco-care offers much more activities. Though we stepped into the muddy river and got wet and dirty, we enjoyed working together. All the participants were not afraid of dirty, rain, heat, and any other difficulties once we were informed the date of the planting activity. We spent a significant amount of time because we wanted the community work, wanted to plant trees. We looked for seedlings, watched their growths, and many other activities we did together ${ }^{17}$.

Mangrove planting attracts fishermen for several reasons: it emphasises merit on fishery resource by stressing a role of mangrove as an incubator of fish juveniles. It also underlines a role of mangrove as a buffer against tsunami. In addition, fruits of planting activity are explicit because planted trees grow rapidly. In comparison with mangrove project, turtle project may well give fishermen impractical impression. Its results will be proven only after a few 
decades, while its ideal for grass-roots management so far as results in pile of meetings is concerned.

In short, "improper target" and "only on one beach" are key words representing scepticism of fishermen concerning the tangibility of communitybased conservation. "Pile of meetings," tells their unfamiliarity with the concept behind the project. These ideas undermined support for community-based programs.

\section{Conclusion}

Up to here, the paper reviewed how community-based conservation was interpreted, introduced and practised in Malaysia through a case study on sea turtle conservation in Terengganu state. It further described how local people felt about the new attempt.

The innovative features of the original concept have lost even at the first stage of localisation. Local elites stressed leading role of the government and practical merits for the managers when they introduced the new concept. In the case of Terengganu, transformation also occurred in field level. Field officers, in practice, implemented the new approach as if it were a minor modification of top-down approach they had been familiar with. In short, the studied case fails to incorporate grass- roots autonomy and horizontal dialogue, while they were vital essences of the original concept.

A curious fact is that fishermen were also embarrassed with the unfamiliar approach. It is not a surprise that the dialogue sessions failed to invoke lively arguments in Malaysian rural society where no tradition of grassroots democracy has existed. Without any function for decision making, dialogue sessions turned into unattractive rituals. The project was consequentially faced with the passive resistance of fishermen as Womgbursarakum had described.

A study on community-based projects in South East Asian countries should consider how society would localise and transform the new thought. It should also examine how customs and traditional way of thinking give influences on the process. The new approach awaits further studies on its localisation processes. 


\section{Endnotes}

1 This corresponds to the number of the fishermen's households listed on the member list of fishermen's association of these settlements.

2 For further detail on grounded theory approach, see Glaser and Strauss (1967) or Strauss (1987).

3 Unit Perancangan Ekonomi Negeri Terengganu \& Department of Fishery Malaysia (1987). pp.12.

${ }^{4}$ ASEAN Secretariat, op. cit.

${ }^{5}$ Ibrahim was the director of Turtle and Marine Ecosystem Research Centre and the director-general of the department of marine parks. Sharma was the President of WWF Malaysia. Both persons have great influence on marine conservation policy in Malaysia.

${ }^{6}$ Interview with Abdullah Halim mat Noor, Chief of Rantau Abang Sea Turtle Information Centre and the Manager of Ma'daerah sea turtle sanctuary, on 9th July 2007 in Rantau Abang

7 Ibid.

8 Interview with Rahayu Zulkifli, the WWF program officer in charge of Ma'daerah, 26 August 2007.

${ }^{9}$ Interview with Interview with Amran Salleh, head master of Kerteh elementary school and chief of persatuan Ma'daerah Khazna Rakyat, August 2007, at Kerteh, elementary school. The original text is in Malay and translated by the author.

${ }^{10}$ Interview with Rahayu Zullifili, op cit.

11 Interview with Ramlee Abdullah, chief of fishermen association in Kerteh and Kemaman district. He was also a former chief of Persatuan Ma'daerah Khazna Rakyat. The original text is in Malay and translated by the author.

12 Ibid.

${ }^{13}$ Interview with informant no.3, a fishermen from Rabohan village, Kertheh. He was also a part-time ranger worked at Ma'daerah sea turtle sanctuary, May 2007 at Tengah Village, Kerteh. The original text is in Malay and translated by the author.

${ }_{14}$ Group interview with informant no.1, three fishermen from Rabohan village, Kerteh, May 2007 at fishery port of Kerteh. The original text is in Malay and translated by the author

15 Interview with Informant no.22, fishermen from Tengah Village, September 2007. Informant no.3 joined this interview. The original text is in Malay and translated by the author.

${ }^{16}$ Interview with Ramlee Abdullah, op. cit.

17 Ibid. 
Did Localisation of Community-Based Conservation Succeed? A Case Study on Community-Based Sea Turtle Conservation in Ma'daerah Sea Turtle Sanctuary

\section{Reference}

Ahmad, M., Wagiman, S., Ibrahim, K., Ho, S. C., Liew, H. C., Yeo, B. H., Lau, M. M., Basrion, M. N., \&Sharma, D. S. K. (Eds.). (2006). Charting multidisciplinary research and Action Priorities towards the Conservation and Sustainable Management of Sea Turtles in the Pacific Ocean: A Focus on Malaysia. Penang, Malaysia: World Fish Centre.

Aikanathan, S. \& Kavanagh, M. (1988). The effect of fishing on Leatherback turtles. Kuala Lumpur, Malaysia: WWF Malaysia.

ASEAN Secretariat. (1997). ASEAN program and work plan for sea turtle conservation and protection, Jakarta, Indonesia: ASEAN Secretariat

Campbell, L., M. (2007). Local conservation and global discourses: A political ecology of sea turtle conservation. Annals of the Association of American Geographers, 97(2), 313-334.

Campbell, L., M. and Smith, C. (2006). What makes them pay? Value of volunteer tourists working for sea turtle conservation, Environmental Management, 38, 84-98

Crowfoot, J. \& Wondolleck, J. (1990). EnvironmentalDisputes: CommunityInvolvement in Conflict Resolution. Washington, D.C., Island Press.

Department of Fishery Malaysia, WWF-Malaysia, \& BP Malaysia (2004). $M a^{\prime}$ Daerah marine turtle sanctuary centre. Kuala Lumpur, Malaysia: Department of fishery Malaysia; WWF-Malaysia; \& BP Malaysia.

Glaser, B. G., \& Strauss, A. L. (1967). The discovery of grounded theory: Strategies for qualitative research. New York, NY: Aldine.

Hines, E. (2002). Conservation of the dugong (Dugong dugong) along the Andaman Coast of Thailand: An example of the integration of conservation and biology in Endangered Species Research. (PhD dissertation). University of Victoria, Victoria, BC, Canada.

Ibrahim, K \& Sharma, D. S. K. (2006). Forty years of sea turtle conservation efforts Where did we go wrong? -Lesson learned for the way forward. In Ahmad, M., Wagiman, S., Ibrahim, K., Ho, S. C., Liew, H. C., Yeo, B. H., Lau, M. M., Basrion, M.

N., \& Sharma, D. S. K. (EDs). Charting Multidisciplinary Research and Action in Priorities towards the Conservation and Sustainable Management of Sea Turtles in the Pacific Ocean: A Focus on Malaysia. Penang: World Fish Centre.

Jusoh, I. B. (2006). Opening Adress. In Ahmad, M., Wagiman, S., Ibrahim, K., Ho, S. C., Liew, H. C., Yeo, B. H., Lau, M. M., Basrion, M. N., \&Sharma, D. S. K. (Eds). Charting Multidisciplinary Research and Action Priorities towards the Conservation and Sustainable Management of Sea Turtles in the Pacific Ocean: A Focus on Malaysia (pp.21-25). Penang: World Fish Centre. 
Strauss, A. L. (1987). Qualitative Analysis for Social Scientists. Cambridge, UK: Cambridge University Press.

Western, D. \&Wright, R. M. (1994). The Background to community-based conservation. In Western, D. and Wright, M. (Eds.) Natural connections: Perspectives in community-based conservation. Washington. D.C.: Island Press.

Unit Perancangan Ekonomi Negeri Terengganu \& Jabatan Perikanan Malaysia. (1987) .The workshop on sea turtle conservation and management in Malaysia. Kuala Terengganu, Malaysia: Unit Perancangan Ekonomi Negeri Terengganu.

Wongbusarakum, S. (2002) .The Urak Lawoi and the complexity of sustainable

Resource use: the political ecology of change in the Adang Archipelago, Andaman

Sea, Thailand. (Doctoral dissertation). University of Hawaii at Manoa, HI.

Yamao, M. (1997). The perspective of Fishers Organizations Integrated to Coastal Fisheries Management - Through Experiences Gained in Thailand. In Proceedings of The Regional Workshop on Coastal Fisheries Management Based on Southeast Asian Experiences (pp.295-312). Bangkok, Thailand: South East Asian Fisheries Development Centre. 